\title{
THE SENSE OF COMMUNITY BELONGING AMONG INTERNALLY DISPLACED PERSONS WITH HIGH LEVEL OF LIFE SUCCESSFULNESS
}

The situation of military conflict in Donbas and occupation of Crimea became causes for the forced displacement of about 1.5 million of Ukrainian citizens. Those people faced different problems connected with social, psychological, economic, political and other factors during and after resettlement. Thus, they had to adapt to a new situation in different ways to recover and to get back to normal life.

The social environment is one of the factors, which is essential for a person's adaptation in new circumstances. The in-group (in our case a group of internally displaced persons) can be a great support, but the out-group (in our case local groups) could provide with possibilities which will help to reach a level of normal life after resettlement.

The main goal of this article is to understand to what extent internally displaced persons with a high level of life successfulness associate themselves with the community of resettlers, to investigate what lays in the background of person's association or disassociation him/herself with the community of internally displaced persons.

The sense of community belonging is considered in the article within the framework of immigration and displacement. The theoretical approaches to the sense of community belonging in common groups and groups of migrants are presented, and their comparative analysis is made. For a better understanding of the resettlers situation, the comparative analysis of main factors that influence on difference between immigrants and internally displaced persons is presented.

The results of qualitative descriptive research held among internally displaced persons in Ukraine are performed and several tendencies are identified: a strong sense of community belonging to the group of internally displaced persons, an absence of the sense of community belonging to the group of internally displaced persons with integration into local communities, an absence of the sense of community belonging to any group neither group of internally displaced persons no local. Every tendency, except the last one, has several variants which help to explain its content and potential causes of the sense of community belonging appearance and absence among internally displaced persons.

Key words: integration, host community, IDP community, adaptation, displacement.

Problem setting. The problem of displacement is every year increasing on a worldwide basis. Internal and external conflicts and wars are the main factors which influence the migration process inside a country. Ukraine is not an exception. People who experience displacement are rather vulnerable and face a set of problems connected with the forced changing of habitation. The main question that confronts specialists from different fields is how to help those people to adapt to new conditions, to save mental health and to have an appropriate quality of life.

One of the factors that influence successful adaptation, ability to built a new life and further satisfaction is integration into host community/communities. As B. Arpino and H. de Valk mention in their work "integration and links to the host society are crucial for life satisfaction" [1, p. 1166]. At the same time, the sense of belonging to the IDP community and sharing common experience gives a feeling of understanding, acceptance and support, which influences dramatically on mental health and mental well-being. From the other side, staying only inside the IDP community and disability to integrate into the host community negatively reflects on the adaptation and successfulness levels after displacement [2, p. 30].

In such case arises the dilemma of what strategy is more useful for the fast adaptation and further life successfulness: to integrate into the host community, to stay inside IDPs community or to make an attempt to develop and implement own.

Goal setting. This article aims to investigate main tendencies connected with the integration into host community/communities and the sense of belonging to the IDPs community among resettlers with high rates within life successfulness scale.

Theoretical background (Literature review). If talking about sense of community belonging, we can find the first mentioning of this term in the work of Seymour B. Sarason in which the author says that it reflects ".... the sense that one belongs in and is meaningfully part of a larger collectivity; ... the sense that there is a network of and structure to relationships...." [3, p. 41]. At the same time, Sarason notices that the term is not familiar for psychological science and "... it does not sound precise, it obviously reflects a value judgment, and does not sound compatible 
with "hard" science. It is a phrase which is associated in the minds of many psychologists with a kind of maudlin togetherness, a tear-soaked emotional drippiness that misguided do-gooders seek to experience" [3, p. 156-157]. Also Sarason offers in his work the next characteristics of the sense of community: the feeling of similarity to other community members; acknowledged interdependence among the members of the community; the desire to maintain this interdependence; the feeling that one is a part of a stable superior social structure [3, p. 157].

Further development of the theory of the sense of community belonging was made by McMillan and Chavis (1986) who offered the following definition: "Sense of community is a feeling that members have of belonging, a feeling that members matter to one another and to the group, and a shared faith that members' needs will be met through their commitment to be together" [4, p. 9]. Also, the authors proposed a four-dimension concept of the sense of community. This concept consists of membership, influence, integration and fulfilment of needs, and shared an emotional connection. All the concept's elements are considered to "... work dynamically together to create and maintain a sense of community" [4, p. 15]. Let us look precisely at all the components of the concept offered by McMillan \& Chavis:

- the first component - membership reflects the feeling of belonging to the group. It consists of the next elements: boundaries - markers, which define who is in group and who is out; emotional safety - feeling of security, protection of group intimacy; a sense of belonging and identification - a feeling that person has his/her own place in the group and fits it, a feeling of acceptance by the group; personal investment working for membership that gives a feeling that one has earned a place in the group, personal investment into the group; a common symbol system - indicators that help to differ members from nonmembers;

- the second component - influence is considered as a bidirectional concept. From one hand, a member to be a part of the group should have some influence over what the group does. From the other hand, to have the feeling of togetherness and cohesiveness group should influence its members;

- the third component - integration and fulfilment of needs means that to maintain the sense of membership and belonging, the individual-group association have to be rewarding. Among main reinforces the next could be specified: the status of being a member; other members' competences; shared values;

- the last component - shared emotional connection is based on shared history or at least on members' association with this history if they did not participate personally. The following hypotheses are considered as a base for shared emotional connection: contact hypothesis - the more interaction - the more closeness; quality of interaction - the more positive experience - the greater cohesion; closure to events - group cohesiveness could be inhibited in case of ambiguous communication and unresolved community tasks; shared valent event hypothesis - the more important event to the members - the greater community bond; investment - the more time and energy donation to the group - the highest emotional engagement; the presence of reward or humiliation has a significant influence on emotional involvement of community members; spiritual bond.

Currently sense of community has been researched in different social dimensions including the working environment (S. Burroughs L. Eby, B. Zani, E. Cicognani, G. Harris, J. Cameron, G. Pretty, M. McCarthy), religious communities (I. Hussey, N. Krause, E. Bastida, L. Smith), immigrant communities (Sonn, B. Salami et. al., P. Kitchen et al.), student communities (K. Osterman, R. Dukynaitè, J. Dudaitè, L. Johnson), virtual communities (S. Malinen, J. Koh, Y. Kim), communities based on age and gender (E. Cicognani, B. Zani, C. Albanesi, S. Jakubec, M. Olfert, L.Choi, N. Dawe, D. Sheehan) and et cetera.

For this paper, it is essential to consider the sense of community in the context of migration, resettlement and displacement.

Based on the ideas of McMillan \& Chavis and their four-dimension concept of the sense of community, and Gallimore et. all understanding of activity settings which they considered as “... a perceptible instantiation of the ecological and cultural system which surrounds the family and the individual $<\ldots>$ the everyday conduits through which social and cultural institutions affect children's experiences and their development $<\ldots>$ To study these activities is to identify the cognitive and communicative opportunities provided by culture" [5, p. 539], C. Sonn described the process of immigrants' adaptation through the sense of community. According to his investigation, there were four main factors:

The first factor reflected items that showed preference to socialize with a native group after immigration, the desire to form social connections with this group and to maintain their own culture and traditions. This factor was presented as Shared emotional connection, and its basis was on a shared background. Respondents mentioned that they enjoyed being with others from a native group because of a sense of familiarity. Being with fellows allowed reminiscing and sharing stories about their lives in their motherland and the new place.

The aspects of Influence presented the second factor - precisely, the issues that reflected individual and group control over behaviour. The factor specified levels of control and conformity within the group, especially, "the perceived control that people feel they have over others and the perceived control the group may have over members' behaviour. In the settings, there are pressures for members to 
conform to expectations of the community while at the same time, members may try to influence others in the group" [6, p. 215].

The third factor reflected items contained "some of the benefits associated with group membership and constituted integration and fulfilment of needs".

In the author's interpretation, the questions that loaded this factor suggested that: ethnocultural social networks can play a positive role in the experience of the community; people have an opportunity to ensure the continuity of their cultural community, which is central for the maintaining of an ethnic identity; members of an in-group can maintain and propagate valued cultural stories and traditions in different settings; connection with others from the same group is essential in providing safety and opportunities for social identity development, being a member of the group also linked people with the broader sociocultural context.

The fourth factor reflects perceived, tangible and subjective support. "The factor reflected perceived support, that is, the belief among people that they could depend on each other for different forms of social support" [6, p. 216].

As we can see, there are some differences in Sonn's and McMillan \& Chavis's investigations:

1. In Sonn's research, we can see that the most loaded factor is Shared emotional connection while in McMillan and Chavis's concept we can see a feeling of belonging at the first place and shared emotional connection is on the last place.

2. In Sonn's investigation, there is no separate factor that reflects a feeling of belonging to the group and all the components of this concept: boundaries, emotional safety, sense of belonging and identification, personal investment, common symbol system. To our point of view there could be several reasons: first all those indicators of belonging could be parcelled through other factors, second - there is no such a great importance to point out the boundaries, special symbols or signs of identification purposefully when you are an immigrant, because you speak another language or you have another colour of skin (as in Sonn's research), or you live in a place where all the immigrants live.

3. It is interesting that in Sonn's investigation, we can see social support as a separate factor while in McMillan \& Chavis's concept, we do not observe it. Of course, it could be included in one of the four factors, but it is not presented as an individual one.

Thus, we can see that there are some peculiarities in the sense of community belonging among immigrants and common communities. Going back to the main task of our research, it should be emphasized that there is a difference between immigrants and internally displaced persons as well:

- Voluntariness of changing a place: if migrants do it voluntarily, IDPs experience forced displacement;
- Reasons of changing a place: if immigrant usually are searching for improvement of their lives (finding work, seeking better education, reuniting with family), IDPs want to escape danger (to avoid the effects of armed conflict, situations of generalized violence, violations of human rights or natural or human-made disasters);

- The direction of relocation: outside the country for immigrants, inside the country for IDPs. It is also worth saying that immigrants get into the new cultural and social context in this case, while for IDPs this context stays the same more or less;

- Possibility to return home: IDPs cannot safely return home, immigrants can if they want $[7 ; 8]$;

- Legal protection: immigrants are protected by international migration law (which is an umbrella term covering a variety of principles and rules that together regulate the international obligations of States concerning migrants. Such broad range of principles and rules belong to numerous branches of international law such as human rights law, humanitarian law, labour law, refugee law, consular law and maritime law [9]) or laws of the country of relocation. These laws do not protect forced internal migrants as they are displaced within national boundaries.

- The trigger event: for IDPs the trigger event for displacement, usually comes with some level of trauma while the reason for relocation for migrants usually is deliberate and well-considered.

- Possible negative aftermath of relocation: both IDPs and migrants could face stigmatization for some extension; there could be a lack of adequate health care/finances/education, broken social networks for both groups, but it worth saying that IDPs experience could also be enhanced with displacement trauma and disintegrated sense of hope for a future [10, p. 19-20].

Basic Material. For our study, we used a method of in-depth interviews. Participants of our study were internally displaced persons with a high level of life successfulness from both Donbas and Crimea. The level of life successfulness was detected on the previous stage of our research with the questionnaire designed by us. Participants were recruited among the clients of different NGOs, charity foundations and online within special groups for IDPs.

A total of 17 participants with a high level of life successfulness were engaged in individual interviews. All the interviews were held at a suitable time for participants both personally and on Skype (some of them were in different regions of Ukraine). Interviews lasted from 30 minutes to 1.5 an hour; the average time was about 45 minutes. We used open-ended questions, and our guide was semistructured. The main questions about community belonging included the following: (a) What community do you feel you belong? (b) What is the role of community belonging in a person's life 
successfulness? (c) Do you feel yourself as a part of IDPs community? Why?

All the interviews were recorded and then transcribed verbatim. After that we made a thematic analysis which is considered as a "... the sense you are making of the data and categories" [11, p. 241] It is a process of identifying and analyzing repeated patterns and meanings inside the data. Based on this analysis, we highlighted the typical tendencies in which resettlers develop a sense of community belonging within IDPs or other groups.

l. The strong sense of community belonging to the IDP group.

It worth saying that in the case of IDPs in Ukraine person's association with the group of resettlers is especially important during the first years of relocation. Many respondents notice that the intensity of belonging to IDPs decrease with time:

Informant 2: When we relocated, the first year, probably, we communicated with those people (IDPs) with whom we understood that we think about the same. You know every telephone conversation, because everyone was spread along with all the country, every telephone conversation finished with the words that we can do it, everything will work out well.

Informant 12: When everyone started to relocate massively for me, it was essential to feeling this sense of community, that you are not alone.

Informant 13: ... the first year we communicated a lot and not only online, but there were also some meetings and evenings... Now it, of course, went away...

In the beginning, belonging to the IDPs community for resettlers could also have a therapeutic effect. As J. Herman mentions in her work "the restoration of social bonds begins with the discovery that one is not alone... Because traumatized people feel so alienated by their experience... The encounter with others who have undergone similar trials dissolves feelings of isolation, shame, and stigma... Participants repeatedly describe their solace in simply being present with others who have endured similar ordeals" [12, p. 290-291]. The evidence of such therapeutic effect we can see in the statement of one of the respondents:

Informant 12: I remember that meetings in Izolyatsia when we came, sometimes we kept silence and didn't get acquainted but this feeling that you are not alone - it was essential. ...if it whelms me in this context (with outcomes of displacement), it is evident that I will go to the people who also experienced this (forced relocation) because I don't need to explain them.

Strong sense of community within the IDPs group could occur when belonging to this group covers several important for person spheres of life. For example, for one person belonging to the
IDPs community reflects only the sphere of Social Environment, and for another person, it also covers the spheres of Professional and Personal Realization. For the second one, the sense of community belonging will be stronger than for the first one.

Informant 1: I felt comfortable when I saw that there is a problem, and I am participatory (during voluntary work)... If I just went for work and understood that I do nothing in the moment of an acute crisis, I would never felt successful.

In the case mentioned above, we can see a woman who was displaced and who chose to become a volunteer and to help other IDPs at the beginning of her relocation (about five months). All her career after relocation was somehow connected with IDPs, and she associates her personal and professional success with helping IDPs. Her sense of belonging to the IDP community is very strong from the very beginning until now.

Informant 9: We are an example here (in the town of relocation) for our resettlers because I am a Head of Initiative group of IDPs for all five years. My own example, willing or not, tired or not, we are going ahead together and overcoming obstacles together.

In this case, connection with IDPs community is also spread into several life spheres, and we can observe a long-lasting sense of community belonging to IDPs.

Getting benefits of belonging to IDPs. Referencing to the Sonn's and McMillan \& Chavis theories we can also see that in our case belonging to the community gives the members benefits both material and psychological which makes the members of the community feel a connection with it:

Informant 2: (Name of a charity fund for IDPs) they, first of all, supported me. How did they support? I attended different courses: marketing, copywriting and something else. I understood that there are people who take care of others and in such manner, I abstracted myself (from the problems connected with displacement). Secondly, in (Name of a charity fund for IDPs), there was an opportunity to get information about the grant program. I had a long way there (to the grant program), I came, I got, I won, and now I work (as a private entrepreneur).

Informant 14: I like it very much because I get endorsement everywhere. Privat entrepreneur, IDP is making something... It is delightful to hear praise.

Informant 15: There were several projects in which I took part. They related to travelling to other cities, and some projects were connected with the teaching of entrepreneurs and representatives of small business. I wanted to develop in this direction as well, so I attended courses and got certificates.

One more interesting phenomenon which we discovered during our research is relocation/ recreation of habitual community. One of the informants said that they used to find different kind 
of specialists within the group of IDPs. Another informant reported the case of her friend, who a kind of recreated her usual community on the new place.

Informant 13: The person from Donetsk made our kitchen furniture. My hairdresser is from Donetsk. There are a lot of people (IDPS) and if you need someone... My friend needed a dentist not long time ago, and I advised her to ask online in our group for IDPs.

Informant 16: There is this Donetsk community, which help each other... One of my friends buys clothes from people who had sold it to her in Donetsk. She has the same doctors and hairdressers which she had in Donetsk. It seems like... someone took her environment... a piece of a city... put it here and she is keeping living in the same environment.

It worth saying that not all IDPs are considered as the members of the community which person belongs to, but only those with whom he/she has shared values, world view or successful experience of cooperation.

Informant 1: I have this community because it was formed from those values, which are essential for me and those people (who are in the environment) ... for those people social changes are essential, and it is essential those changes be qualitative, not only quantitative.

Informant 9: We particularly communicate with those people who have a strong civic position, strong. They inspire us, and we are keeping such a community. We have them in social media, here and there, about a hundred people, who inspire me and whom I inspire.

Informant 14: Now we call each other "grant crowd". We met each other in different grant projects. With many people, we have a partnership already because all of us support small business.

II. The absence of community belonging to the IDP group. Several reasons could explain this:

Good level of integration occurs when a person starts to associate him/herself not only with the group of IDPs but also with local groups (professional, groups on interest, sport, citizens of the city where they live now). Due to the passage of time and because of increasing the adaptation level, the level of association with the group of resettlers could decrease and fade away.

Informant 8: I am a member of my team. It is a place for children with special needs. Not everyone could work there, and not everyone will stay. Those who stayed are a very cohesive team. At the same time, through this, I am a part of the community of special educators. In this community, I mix under the frame of my work. As well as I am a part of all communities connected with my hobbies. There is a community where I do yoga, where I dance, where I create... I have a little contact among IDPs, and I am acquainted with them thanks to something mentioned above.
Informant 16: ...l have friends not only among those who are from Donetsk, but I also have a broader spectrum of communication. My colleagues say that I am the only one from our team, which relocated from Donetsk, who adapted and assimilated in Kyiv. I do not think that I am the only one, but... if you look at my colleagues, you can see that they all go to see each other, spend free time together, have a friendship with old friends from Donetsk.

Informant 11: ...moreover, if I keep in touch with someone, they are not IDPs. That are more people with whom it is interesting to communicate. It is easy for me to find interesting people in the new environment.

Stigmatization of IDPs. If there was an experience of rejection or abuse from the local community, then it is better not to show one belongs to IDPs, because this could decrease his/her chances for successful adaptation (it is hard to find job or place to live, to integrate into a local community, et cetera). As Pretty et al. mention their work, "that promote division and negative mental health states for those who may be excluded from the benefits of community membership and resources" [13, p. 4].

Informant 8: First half a year no one employed me, because they did not trust. I am an economist, and I have experience in sales what produces responsibility: financial, fixed assets and sometimes cash accountability. They did not trust me. They thought that I take everything and will be back to Donetsk.

Informant 4: you know, there are a lot of situations when, for example, people are looking for the apartment for rent and they are told that "no, we will not take you with your (Donetsk, Luhansk) registration"... or they went to get some subsidy, and someone starts to dab with finger that "you are so and so" or on the working place they can hear "you are from there, you have such a world view".

According to the International organization for migration "IDPs achieve local integration when they: (i) no longer have specific assistance and protection needs and vulnerabilities that are directly linked to their displacement and (ii) enjoy their human rights without discrimination on account of their displacement" [14, p. 7].

Absence of shared values and worldview with the most significant part of IDPs. As we all know, the community is based on shared values and worldview. Some of the IDPs do not associate themselves with the group of resettlers because their values differ from those what communicate the most significant part of the community.

Informant 11: I try to abstract myself from IDPs now. I do not judge them. I understand why... Nevertheless, the significant percentage of them are "all is lost", " all are guilty", " all is bad", " all owe us".

Informant 3: Internally displaced persons... we met a lot, I attended different pieces of training 
and grant programs. Those people are mentally traumatized. They need additional attention; they need special treatment. I do not need special treatment; I do not want it, and I have never asked for it.

Informant 8: This separation me to some particular segment of the people; it makes me tired and sometimes annoys. If it were absent, it would be easier for me. When I was on the list for help and got it from social services, many people massed and started to pity each other. It made me crazy. I think it is a kind of worldview to see everything in black colour and to pity oneself.

It also worth saying that personal peculiarities play a role in the sense of community belonging. During our research, we faced with a case when people were saying that they prefer not to belong to any community, either IDP or local.

Informant 3: If talking about community, what appears in my head is an association with "collective irresponsibility". It is impossible to feel successful somewhere in a ruck. Maybe not ruck, but some kind of community... community of some direction, but you cannot feel as an individuality. It is not right to apply collective achievements to yourself. You cannot apply collective achievement as your own, as your development.

Informant 16: sometimes, I want to be a part of some community, but I choose not to be.

We suggest that in this case, the reason for such peculiarity could be the individual level of individualism versus collectivism orientation. It worth saying that among people with more individualistic orientation well-being and life successfulness "is perceived to be an individual responsibility" [1, p.1166] and therefore association with any community is taken as an attempt to share this responsibility. Thus, people with a high level of individualism tend not to be a part of a community.

Conclusions and further research. As we can see from our research, there are three main tendencies concerning the sense of community belonging to IDPs among resettlers with a high level of life successfulness.

The strong sense of community belonging could be observed during the first years of relocation. Meetings with other IDPs in this period could have a therapeutic effect. The sense of belonging to IDPs could be prolonged due to the next factors: if belongingness covers several essential spheres of person's life; if a person gets benefits from membership; if other IDPs surround a person with the same values and they form a smaller group.

The next tendency is the absence of community belonging to IDPs. When a person starts to associate him/herself with local groups, we can say about a good level of integration which can cause weakening of connection with IDPs. Another reason is stigmati- zation of IDPs when it is not beneficial to say where a person is from for not being excluded from the resources (job, accommodation). The third reason is the absence of shared values with the most significant part of IDPs when person disassociates from this community because of the difference in worldview and approaches to life.

The last tendency which we identified during our research is a tendency of disassociation with any community due to personal peculiarities.

As for further research, it would be helpful to make a quantitative investigation of sense of community belonging among IDPs with different length of relocation and use this information for effective IDPs adaptation and integration.

\section{References:}

1. Arpino B. Comparing Life Satisfaction of Immigrants and Natives Across Europe: The Role of Social Contacts. Social Indicators Research. 2018. Vol. 137. Issue 3. Pp. 1163-1184.

2. Sense of community belonging among immigrants: perspective of immigrant service providers. Public health. 2019. No 167. Pp. 28-33.

3. Sarason S.B. The psychological sense of community: prospects for a community psychology. San Francisco : Jossey-Bass. 1974. 285 p.

4. McMillan D.W. Sense of Community: A Definition and Theory. Journal of Community Psychology. 1986. No 14. Pp. 6-32

5. Gallimore R.G. The social construction and subjective reality of activity settings: Implications for community psychology. American Journal of Community Psychology. 1993. Vol. 21. No 4. Pp. 537-559.

6. Sonn C.C. Immigrant adaptation: Understanding the process through sense of community. The Plenum series in social/clinical psychology. Psychological sense of community: Research, applications, and implications. New York : Plenum Publishers, 2002. Pp. 205-222.

7. International Organization for Migration. Key Migration Terms. International Organization for Migration. URL: https://www.iom.int/keymigration-terms.

8. Habitat for humanity. Refugees, Asylum Seekers \& Migrants: A Crucial Difference Habitat for humanity. URL: https://www.habitatforhumanity.org.uk/ blog/2016/09/refugees-asylum-seekers-migrantscrucial-difference.

9. International Organization for Migration. What is International Migration Law? International Organization for Migration. URL: https:// www.iom.int/migration-law.

10.Siriwardhana C. Forced migration and mental health: prolonged internal displacement, return migration and resilience. International health. 2013. No 5. Pp. 19-23. 
11. Rossman G. An Introduction to Qualitative Research: Learning in the Field. Thousand Oaks, California : SAGE Publications. 2016. 344 p. (4th edition).

12. Herman J. Trauma and Recovery : The Aftermath of Violence-From Domestic Abuse to Political Terror. New York : Basic Books. 2015. 336 p.

13. Psychological sense of community and its relevance to well-being and everyday life in Australia.
The Australian Psychological Society. 2006. URL: http://groups.psychology.org.au/Assets/Files/ Community-Updated-Sept061.pdf.

14.Reasons to remain (Part 2): Determinants of IDP integration into host communities in Iraq. International Organization for Migration. 2019. URL: https://iraq.iom.int/publications/reasons-rema in-part-2-determinants-idp-integration-host-communities-iraq.

\section{Боровинська І. Є. Відчуття приналежності до спільноти серед внутрішньо переміщених осіб із високим рівнем життєвої успішності}

Ситуація воєнного конфлікту на Донбасі й окупація Криму стали причинами вимушеного переїзду для більш ніж 1,5 мільйона українців. Ці люди стикнулись з різними проблемами, викликаними соціальними, психологічними, економічними, політичними та іншими чинниками під час і після переселення. Таким чином, їм довелося пристосовуватися до нової ситуації різними способами, щоб відновитися $і$ повернутися до нормального життя.

Соціальне оточення - це один із сутmєвих фракторів для адаптації особи на новому місці. Спілкування всередині своєї групи (у нашому разі спільнота внутрішньо перемішених осіб) може стати хорошою підтримкою, особливо на початкових етапах після переселення, але група інших (у нашому разі місцева громада) може забезпечити можливостями, які допомагають досягти нормального рівня життя після переселення і в економічному, і в соціальному сенсах.

Головна мета цієї статmі - зрозуміти, якою мірою внутрішньо переміщені особи з високим рівнем життєвої успішності співвідносять себе зі спільнотою переселенців, виявити, що є підгрунтям для асоціації або дисасоціації особи зі спільнотою внутрішньо переміщених осіб.

Відчуття приналежності до спільноти розелядається у статті в межах процесів імміграції і переселення. Презентовано теоретичне обгрунтування відчуття приналежності до спільноти серед груп звичайних людей і груп мігрантів, представлено їх компаративний аналіз. Для кращого розуміння ситуації внутрішнього переселення представлено порівняльний аналіз основних фракторів, що впливають на переміщення серед мігрантів і внутрішньо переміщених осіб.

Представлено результати якісного описового дослідження, проведеного серед внутрішньо переміщених осіб в Україні, в ході якого виявлено декілька основних тенденцій: сильне відчуття приналежності до спільноти внутрішньо переміщених осіб; відсутність відчуття приналежності до спільноти внутрішньо переміщених осіб з інтеграцією у місцеві спільноти; відсутність відчуття приналежності до будь-якої спільноти (і до місцевої, і до спільноти внутрішньо переміщених осіб). Кожна тенденція, окрім останньої, має декілька варіантів пояснення їі змісту і потенційних причин появи або відсутності відчуття приналежності до спільноти серед внутрішньо переміщених осіб.

Ключові слова: інтеграція, місцеві громади, спільнота ВПО, адаптація, переселення. 